\title{
Statistična ocena protipožarne varnosti večstano- vanjskih zgradb v Sloveniji
}

Skoraj tretjina stanovanjskih enot v Sloveniji se nahaja v večstanovanjskih objektih. Večina tovrstnih zgradb je bila zgrajena po drugi svetovni vojni, ko je bila potreba po ustreznih nastavitvenih objektih največja. Narejeni so bili $\mathrm{v}$ okviru gradbenih možnosti in zahtev časa. Vsako leto v teh objektih izbruhne več kot 200 požarov s smrtnimi žrtvami in $\mathrm{z}$ veliko gmotno škodo.

Zaradi velikih naporov v preteklih stoletjih, ki so bili usmerjeni predvsem $\mathrm{v}$ zamenjavo gorljivega gradbenega materiala $\mathrm{z}$ negorljivim in $\mathrm{z}$ razvojem gasilske službe, sta se število požarov in njihov obseg zmanjšala, vendar ne odpravila. Nov, večji napredek na področju požarne varnosti večstanovanjskih zgradb je tako očiten šele v zadnjih nekaj letih, ko veljajo tudi strožji predpisi za gradnjo tovrstnih objektov. Razvoj znanosti in stroke je tudi na tem področju prinesel več novih rešitev za izboljšanje stanja, kar potrjujejo izkušnje iz tujine. Žal je pri nas uveljavitev varnostnih principov še vedno odvisna predvsem od zavesti uporabnikov, finančnih sredstev, hkrati pa so določeni postopki izvedbe bistveno bolj zapleteni zaradi novih lastniških razmerij.

S pomočjo statističnih rezultatov popisa 2002 in sodobnih zahtev varstva pred požarom se želi v članku prikazati današnje stanje tega problema na državni in občinski ravni ter nakazati možnosti izboljšanje stanja.

Avtorja v članku ugotavljata, da sodobnim zahtevam ne ustreza pravzaprav nobena starejša večstanovanjska zgradba. K sreči izboljšuje stanje na tem področju dejstvo, da je večina objektov pri nas zgrajena iz negorljivih materialov (beton, opeka), ki omejujejo širjenje požara.

Ključne besede: požar, protipožarna varnost, večstanovanjske zgradbe, Slovenija 


\section{Uvod}

V Sloveniji živi v večstanovanjskih zgradbah velik del prebivalstva, zlasti mestnega. Iz rezultatov popisa Statističnega urada Republike Slovenije v letu 2002 je razvidno, da je bilo takrat v Sloveniji 18.005 večstanovanjskih zgradb, kar je pomenilo le 3,9\% vseh stanovanjskih zgradb, vendar je bilo v njih 242.011 stanovanj oziroma skoraj tretjina stanovanj v državi (Statistični urad Republike Slovenije, 2009).

Te zgradbe so večstanovanjske hiše, bloki in stolpnice. Intenzivnost gradnje večstanovanjskih zgradb je bila vedno povezana $\mathrm{z}$ rastjo in $s$ priseljevanjem prebivalstva $\mathrm{v}$ določeno okolje. Kakovost in obseg gradnje sta ustrezala željam in zmožnostim investitorja in gradbene stroke ter varnostnim zahtevam, ki so $\mathrm{v}$ tistem času veljale za gradnjo tovrstnih objektov (Kilar in Kušar, 2009; Slak in Kilar, 2005; Vidrih, 2008).

Ti objekti še vedno služijo svojemu namenu, vendar so danes zahteve glede udobnosti, uporabnosti in varnosti višje, kot so bile ob zgraditvi objekta. V Sloveniji je bilo zato narejenih kar nekaj raziskav večstanovanjskih zgradb, v katerih so te obravnavane na različnih področjih. Ocena potresne varnosti večstanovanjskih in drugih zgradb (Kilar, 2004; Orožen Adamič, 1995; Orožen Adamič in Perko, 1996) je pokazala, da mnoge starejše večstanovanjske zgradbe ne ustrezajo današnjim zahtevam in bi jih bilo zelo verjetno treba sanirati. Analize ogrevanja in toplotnih izgub prav tako potrjujejo veliko potrebo po toplotni sanaciji tovrstnih zgradb, saj ne ustrezajo sodobnim zahtevam (Šijanec-Zavrl, 1997; Tomšičc, 2005).

V večstanovanjskih zgradbah v Sloveniji vsako leto izbruhne okoli 250 požarov. Ta številka se že nekaj let ne spreminja bistveno, medtem ko škoda zaradi požarov v zadnjih letih narašča (internet 1). Žal je problematika požarov pri nas po krivici v senci drugih nevarnosti, ki ogrožajo zgradbe: potresi, poplave in v zadnjem času tudi vetrovi. Vzrok za to je verjetno dejstvo, da požari niso tako siloviti in ne povzročijo tako velike hipne škode kot druge nesreče, zato so manj medijsko odmevni.

$S$ požarno problematiko večstanovanjskih zgradb se po svetu spopadajo različno. V Združenih državah Amerike so se problema požarov $\mathrm{v}$ večstanovanjskih zgradbah lotili z sprejetjem ukrepov za namestitev naprav in sistemov za aktivno požarno zaščito (sistemi za odkrivanje požara in avtomatsko gašenje požara). Tako je konec leta 1992 začel veljati predpis Fire Administration Authorization Act of 1992 (PL 102-522) o ukrepih za zaščito večstanovanjskih zgradb pred požarom
(Bukowski in Budnick, 1995). Z njimi so stavbni fond države razvrstili v tri kategorije:

- novogradnje, ki imajo 4 nadstropja in več;

- rekonstrukcije stanovanjskih zgradb, ki imajo 4 nadstropja in več;

- ostale stanovanjske zgradbe, ki nimajo več kot 4 nadstropja.

Za vsako od teh skupin so predvideli določene ukrepe za zagotavljanje ustrezne ravni varnosti pred požarom. $Z$ a nove večstanovanjske zgradbe, ki imajo 4 nadstropja ali več, zahtevajo namestitev naprav za odkrivanje požara (javljalniki) in avtomatsko gašenje (pršilniki - t. i. sprinklerji). Pri rekonstrukcijah obstoječih zgradb so zahteve glede pršilnikov nekoliko nižje. Vendar so s predpisom zahtevali, da se mora $\mathrm{v}$ novih in tudi $\mathrm{v}$ vseh obstoječih stanovanjskih zgradbah (eno- in večstanovanjkkih) namestiti javljalnik dima. $\mathrm{Ob}$ tem so bile narejene tudi ekonomske analize o smiselnosti namestitve naprav za samodejno gašenje $\mathrm{v}$ stanovanjih in celo individualnih hišah (Brown, 2005; Butry idr., 2008; internet 2). Podobno razmišljajo tudi v nekaterih delih Evrope (Danska, Švedska, Velika Britanija, nekatere nemške dežele), kjer oglašujejo ali celo zahtevajo uporabo sodobnih naprav za odkrivanje in javljanje požara v obstoječih stanovanjih (Ahačič, 2006; internet 3).

Pregled dosedanjih raziskav kaže, da je pri zagotavljanju požarne varnosti večji poudarek na gradbenih ukrepih za preprečevanje širjenja požara in izvedbo evakuacije, bistveno manj pozornosti pa se posveča analizi vzrokov požarov in načinom preprečitve nastanka teh. Tako Zhao idr. (2004) predstavi model razvrščanja kriterijev za vrednotenje požarne varnosti obstoječih zgradb na Kitajskem, ki temelji na metodi analize hierarhije procesov. Pri tem razdela osnovne kriterije (gradbeni material, možnosti odkrivanja in javljanja požara ter evakuacije, dostopnost za intervencijo, naprave in napeljave za gašenje, upravljanje zgradbe) na podrobnejšse elemente in vsakemu določi utež. Na osnovi podatkov za celotno zgradbo v odvisnosti od pomembnosti posameznih elementov je mogoče analizirati in razvrstiti zgradbe. Podobne metode za vrednotenje obstoječih zgradb imajo tudi Lo (1999), Lo idr. (2005), Watts in Kaplan (2001) ter Wong in Lau (2007). Slednja analizirata 122 starejših visokih zgradb v Hongkongu na osnovi 43 različnih vrst podatkov. Te podatke sicer združi v 5 skupin: lastnosti zgradbe, požarnovarnostne naprave, upravljanje ( $\mathrm{v}$ katero med drugim uvrsti tudi vrste vrat, osvetlitev stopnišč, varnostne napise, dimna vrata ...), naprave in napeljave za odkrivanje, javljanje in gašenje požarov. Da gre pri obravnavi obstoječih objektov za kompleksno področje, kaže dejstvo, da se nekateri elementi pojavijo večkrat. Skupno vsem tem metodam je, da zahtevajo veliko zelo natančnih vhodnih podatkov, zato so uporabne le za vrednotenje posamezne zgradbe ali manjšega števila zgradb. 
Večje število raziskav obravnava obnašanje gradbenih elementov in materialov v požaru. Zanimanje za to področje, posebno pa še za obnašanje jeklenih konstrukcij je postalo izredno aktualno ob iskanju vzrokov za porušitev zgradbe WTC v New Yorku po terorističnem napadu leta 2001 ter po poročilu o porušitvi, ki ga je izdal National Institute of Standards and Tehnology (2005), ki je to nesrečo podrobno raziskal. Cilj teh raziskav je poiskati različne učinkovite načine za zaščito tovrstnih konstrukcij pred porušitvijo zaradi visokih temperatur pri požaru (Goode, 2004).

Glede na hiter razvoj različnih novih materialov in tehnologij, ki omogočajo večjo kreativnost arhitektov in s tem nove možnosti na področju razvoja arhitekture ter hkrati vse večjih zahtev po zagotavljanju varnosti uporabnika, se pojavljajo nova spoznanja tudi na področjih zagotavljanja evakuacije. Osnovnim izračunom časa evakuacije, ki so se opirali predvsem na čas premikanja oseb, so bili kasneje dodani še drugi parametri, ki vplivajo na hitrost evakuacije zlasti s področja psihologije (dojemanje nevarnosti, poznavanje stavbe ...) (Kuligowski, 2008). Na podlagi teh spoznanj so bili narejeni tudi različni programi za modeliranje evakuacije v različnih primerih (Long idr., 2005). Hkrati novi materiali in tehnologije omogočajo požarno varno ločevanje prostorov tudis transparentnimi stenami in vrati ter sistemi, ki samodejno skrbijo za krmiljenje evakuacijskih vrat in drugih elementov evakuacijskih poti.

V Sloveniji je bilo prav tako opravljenih več raziskav (Hajduković, 1995; Rebec, 2006; Žarnič, 2005), in sicer na področjih, ki obravnavajo obnašanje gradbenih materialov, elementov in zgradbe v požaru. Zaradi večje uporabe lesa pri gradnji večstanovanjskih in drugih večjih objektov so bile v zadnjih letih izvedene različne raziskave na področju požarne varnosti lesenih gradbenih elementov (Dujić, 2009; Žarnič, 2005), kot so npr. leseni nosilci ter lesene plošče in stene. Njihovi rezultati dokazujejo, da je les požarno sprejemljiv material, saj pri gorenju nastaja plast oglja, ki ščiti notranjost lesa. Manj raziskav je $s$ področja opečnih in deloma armiranobetonskih konstrukcij. Te naj bi načeloma veljale za požarno varne, čeprav to ne drži povsem (Pajek, 2008).

Z raziskovanjem požarne ogroženosti večstanovanjskih zgradb se je ukvarjal Jug (2005), ki se je osredotočil na procese, ki potekajo pri požaru od nastanka požara, njegovega širjenja, evakuacije, intervencije, in računske metode.

Vsi ti izsledki raziskav pomenijo okvir varstva pred požarom, ki ga normativno ureja Zakon o varstvu pred požarom (Ur. l. RS, št. 3/2007). Ta okvir opredeljuje kot skupek aktivnosti za zmanjšanje nastanka in posledic požara. Mednje sodijo:

- preprečevanje nastanka požara,
- odkrivanje in javljanje požara,

- preprečevanje širjenja požara,

- varna evakuacija ljudi, živali in premoženja ter

- gasilska intervencija z gašenjem požarov.

Spoznanja, pridobljena z raziskovalnim in $s$ strokovnim delom, prenesena tudi v pravne predpise, se uporabljajo pri projektiranju, gradnjah in rekonstrukcijah v današnjem času, medtem ko je obravnava obstoječega večstanovanjskega fonda s stališča požarne varnosti bistveno kompleksnejša. V nasprotju z drugimi avtorji, ki so izdelali modele za vrednotenje posameznih zgradb ali njihovih komponent, smo v članku želeli podati splošno oceno za ves večstanovanjski fond v Sloveniji, ki je bil zgrajen do leta 2002.

Namen raziskave je bil ugotoviti, do kakšne mere večstanovanjski fond, ki je starejšega nastanka, ustreza sodobnimi zahtevam varstva pred požarom. Drugi namen raziskave je bil dopolniti analizo vzrokov za nastanek požarov z novimi podatki in ponuditi ukrepe za njihovo zmanjšanje.

Rezultati so prikazani na ravni Slovenije in tudi na ravni posameznih občin. Rezultati bodo lahko služili občinam in prebivalstvu pri načrtovanju ukrepov varstva pred požarom. Čeprav je raziskava omejena na območje Slovenije, bodo njeni rezultati koristni tudi drugje, kjer so podobne okoliščine kot pri nas in bi želeli stanje izboljšati (predvsem srednjeevropski prostor).

Raziskava je bila opravljena v okviru raziskovalne naloge, $\mathrm{z}$ naslovom »Uvajanje naprednih tehnologij za povečanje varnosti v arhitekturi sodobnih stanovanjskih stavb «, ki sta jo avtorja opravila na Fakulteti za arhitekturo Univerze v Ljubljani.

\section{Metoda}

Temelj raziskave so statistični podatki o večstanovanjskih zgradbah iz popisa prebivalstva iz leta 2002. Del potrebnih podatkov smo dobili na spletnih straneh statističnega urada. Specifične podatke, zlasti pa rezultate križanja želenih podatkov, so nam pripravili pri statističnem uradu. Zaradi obveznega zakrivanja majhnih vrednosti, ki se ga drži statistični urad, občine, pri katerih je podatek manjši od 5, ne smejo biti prikazane. Vendar pa so pa ti podatki upoštevani na državni ravni. Nekatere majhne občine, zlasti na vzhodu države, namreč redko dosežejo 5 večstanovanjskih zgradb.

V okviru popisa so se zbirali podatki, ki so bili zanimivi za naročnika, to je državo. Med zbranimi podatki smo v raziskavi uporabili podatke o: starosti zgradb, materialu nosilne konstrukcije in številu etaž. Žal nekateri podatki, ki bi prispevali $\mathrm{k}$ še boljšim rezultatom te raziskave (lega komunikacij, material 
vhodnih vrat, naprave za gašenje, struktura pročelja ...), niso bili vključeni v popis.

Drugi del raziskave se nanaša na analizo požarov $\mathrm{v}$ večstanovanjskih objektih. Statistiko požarov smo opravili na osnovi podatkov o požarih v večstanovanjskih zgradbah, ki smo jih dobili na spletnih straneh Uprave za zaščito in reševanje Republike Slovenije. Analiza je narejena za leto 2005 ter za obdobje od 1. 10.2006 do 1. 1.2009. To obdobje je bilo izbrano zaradi aktualnosti podatkov in enotne metode pridobivanja ter razvrščanja podatkov o požarih pri Upravi za zaščito in reševanje Republike Slovenije. Opravljena je bila analiza števila požarov, vzrokov za nastanek požarov v večstanovanjskih hišah in prostorov, $\mathrm{v}$ katerih požari najpogosteje izbruhnejo. Analiza je zajela podatke na ravni občin in celotne Slovenije.

Analizirana tri leta dajo realne vrednosti za Slovenijo in večje kraje, medtem, ko so pri majhnem številu požarov in zgradb podatki manj reprezentativni. Zaradi tega tudi občine, ki so imele v obravnavanem obdobju manj kot 5 požarov, niso prikazane, so pa ti požari vključeni v statistiko na ravni države. $\mathrm{V}$ raziskavo na ravni občin je vključenih 154 oziroma $64,3 \%$ slovenskih občin, v katerih pa je kar 17.785 ali 98,8 \% vseh slovenskih večstanovanjskih zgradb.

Zakonska osnova vseh protipožarnih ukrepov v večstanovanjskih zgradbah so ti predpisi, skupaj s podzakonskimi akti:

- Zakon o graditvi objektov (Ur. l. RS, št. 110/2002, 126/2007),

- Zakon o varstvu pred požarom (Ur. l. RS, št. 3/2007),

- Zakon o varstvu pred naravnimi in drugimi nesrečami (uradno prečiščeno besedilo, Ur. l. RS, št. 51/2006),

- Pravilnik o požarni varnosti v stavbah (Ur. l. RS, št. $31 / 2004,10 / 2005,83 / 2005$ in 14/2007),

- Pravilnik o minimalnih tehničnih zahtevah za graditev stanovanjskih stavb in stanovanj (Ur. l. RS, št. 125/2003).

Velika pomoč pri načrtovanju požarne varnosti v zgradbah je publikacija Tehnična smernica TSG-1-001: 2007 - Požarna varnost $v$ stavbah (v nadaljevanju: TSG), ki jo je izdalo Ministrstvo za okolje in prostor RS. Ta povzema dobro prakso in različne tuje predpise o požarni varnosti ter na pregleden in jasen način poudarja osnovne zahteve za požarno varno gradnjo. Prvo tovrstno smernico je izdalo leta 2005, drugo dopolnjeno leta 2007, sedaj pa se pripravlja tudi že nova, še bolj razširjena. Hkrati zakonodaja omogoča tudi zagotavljanje ustrezne protipožarne varnosti po načinu inženirskih metod, ki jih omogoča sodobna (računalniško podprta) tehnologija. Na kratko lahko današnje smernice za protipožarno varnost strnemo v nekaj bistvenih točk (Ministrstvo za okolje in prostor RS, 2007; Zakon o varstvu pred požarom, Ur. l. RS, št. 3/2007):

- konstrukcijski material zgradbe ter ločitveni elementi med stanovanji morajo biti negorljivi, hkrati pa morajo preprečevati prehod požara (ogenj, dim, toplota) iz enega stanovanja v drugo;

- komunikacije v objektu morajo zagotavljati varno evakuacijo, kar pomeni da v teh prostorih ne sme priti zadimljenja, morajo biti ustrezno kratki in ustrezno razsvetljeni;

- zgradba mora imeti ustrezen dostop za gasilce in ustrezno pripravljene površine za gasilsko intervencijo;

- zgradbe morajo biti ustrezno opremljene z sredstvi za gašenje (ročni gasilniki in ustrezna hidrantna mreža za gašenje požarov);

- napeljave in naprave v stanovanjih morajo biti take, da onemogočajo nastanek in širjenje požara;

- zgradbe morajo imeti požarni red, v katerem so navedeni postopki in ukrepanje pri požaru.

\section{Analiza zgradb in obnašanja v požaru}

V članku se obravnava požarna varnost večstanovanjskih zgradb. Pri njih gre za poseben tip zgradbe, namenjene bivanju večjega števila ljudi. Poleg mest so večstanovanjske zgradbe značilne tudi za industrijska in rudarska naselja, $v$ katerih je bilo treba zagotoviti bivališča za zaposlene in njihove družine.
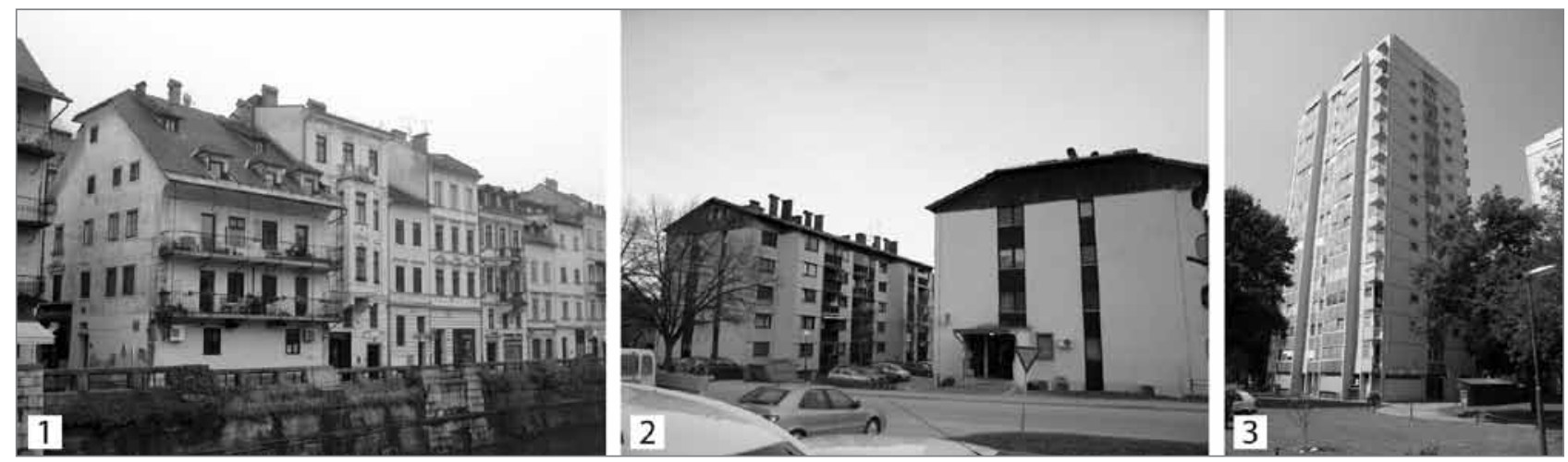

Slika 1: 1 - večstanovanjske hiše v Ljubljani; 2 - blok v Zrečah; 3 - stolpnica v Ljubljani (foto: Domen Kušar) 
Večstanovanjske zgradbe je mogoče deliti na meščanske večstanovanjske zgradbe, bloke in stolpnice (slika 1). Vsak teh tipov ima nekatere značilnosti, čeprav lahko za večstanovanjsko hišo in blok trdimo, da sta si podobna oziroma da gre za isto vrsto zgradbe. Podobno razvršča večstanovanjske zgradbe Statistični urad v popisu iz leta 2002, v katerem je večstanovanjska zgradba opredeljena kot blok, stolpnica ali starejša meščanska večstanovanjska stavba (npr. stavbe v mestnih središčih, ki so zgrajene strnjeno druga ob drugi in po svojem videzu ne spominjajo na sodobne večstanovanjske stavbe) (internet 4).

Najstarejšo kategorijo večstanovanjskih zgradb tvorijo mestne večstanovanjske hiše, ki se na prvi pogled ne razlikujejo od drugih mestnih hiš. Šele notranja struktura kaže členitev zgradbe na stanovanja. Bloki se množično pojavijo med obema vojnama, zlasti pa po drugi svetovni vojni. Prve stolpnice se pri nas pojavijo med obema vojnama, množično pa prav tako šele po drugi svetovni vojni. Takrat postanejo bloki in stolpnice običajne zgradbe za namestitev velikega števila prebivalcev $\mathrm{v}$ urbaniziranih krajih, v katerih sestavljajo tako imenovana blokovska naselja ali soseske.
Po popisu je bilo leta 2002 v Sloveniji 18.005 večstanovanjskih zgradb, kar je 3,9\% vseh stanovanjskih zgradb. V njih se nahaja 242.011 stanovanj, kar znaša kar 31,1 \% vseh slovenskih stanovanj. Največ večstanovanjskih zgradb je v občinah, $\mathrm{v}$ katerih so velika mestna naselja.

V Sloveniji je 40 občin, ki imajo 100 in več takih zgradb. Največji delež zavzemajo $\mathrm{v}$ občinah na Koroškem in $\mathrm{v}$ Zasavju ter na Jesenicah, $v$ Tržiču, Idriji in Velenju (slika 2). Tu gre za posledico močne industrializacije oziroma rudarstva $\mathrm{v}$ določenem obdobju, $v$ katerem je bilo treba zgraditi stanovanja za delavce. Visok delež tovrstnih zgradb v priobalnih občinah (Koper, Izola in Piran) je delno treba pripisati zgodovinsko pogojenemu načinu gradnje $\mathrm{v}$ mestih, delno pa tudi industrializaciji in razvoju različnih dejavnosti (pristaniška, turistična).

Največ stanovanj v večstanovanjskih zgradbah je bilo zgrajenih v letih 1971-1980. Temu obdobju sledita predhodno desetletje (1961-1970) in naslednje desetletje (1981-1990). Med letoma 1961 in 1991 je bila torej zgrajena večina stanovanj v večstanovanjskih zgradba pri nas.

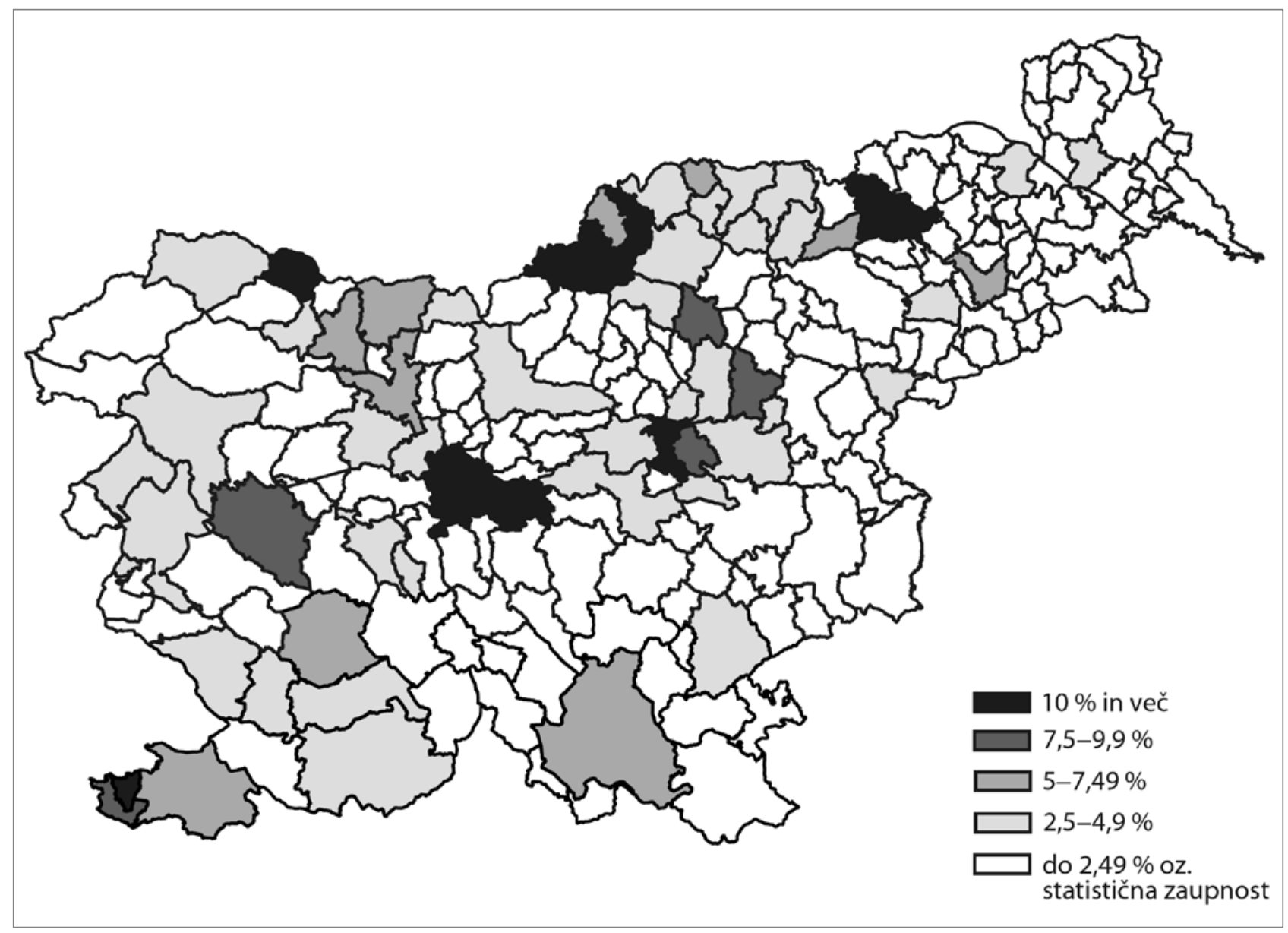

Slika 2: Delež večstanovanjskih zgradb glede na celotno število zgradb, namenjenih bivanju (vir: Statistični urad Republike Slovenije, 2009) 


\subsection{Oblika in višina}

Tipična stolpnica je pravokotne ali celo kvadratne tlorisne oblike in ima pritličje ter najpogosteje od 8 do 12 nadstropij. $\mathrm{Na}$ vrhu je ravna streha in strojnica za dvigalo. Blok je običajno podolgovate oblike in ima zato običajno več komunikacijskih jeder. Običajna višina bloka je pritličje +4 etaže.

Starejše zgradbe imajo višino etaž okoli $3 \mathrm{~m}$, kar ustreza starejšim normativom, zapisanim v gradbenem zakonu iz leta 1931, ki so za višino prostorov zahtevali najmanj $2,80 \mathrm{~m}$. Novejši objekti imajo nekoliko nižjo etažno višino, saj je danes predpisana višina prostorov najmanj $2,50 \mathrm{~m}$ (Pravilnik o minimalnih tehničnih zahtevah za graditev stanovanjskih stavb in stanovanj, Ur. I. RS 125/2003). Pritlični prostori so običajno višji. Tako je višina starejšega večstanovanjskega objekta s pritličjem in še štirimi nadstropji okoli 15 oziroma $16 \mathrm{~m}$, višina stolpnice z 10 etažami pa približno $30 \mathrm{~m}$.

S stališča požarne varnosti so nižje zgradbe načeloma varnejše, saj sta evakuacija in intervencija gasilcev lažji in hitrejši. Prav zato so sodobne zahteve, ki so v TSG določene za visoke zgradbe glede konstrukcije, evakuacije in intervencij, strožje kot za nižje. Kot visoka zgradba se pojmuje zgradba, ki ima višino zadnje etaže višjo od $22 \mathrm{~m}$, merjeno od ravni terena.

\subsection{Gradbeni material}

Večstanovanjske zgradbe pri nas imajo določene skupne značilnosti, predvsem glede gradbenega materiala. Večstanovanjski objekti so bili najpogosteje zgrajeni iz armiranega betona in opeke. Armiran beton prevladuje pri stropih, stopnišcih in prekladah, medtem ko so nosilne stene zgrajene ali iz opeke, betona ali kot prefabricirani betonski elementi. $V$ starejših večstanovanjskih zgradbah so pri stropih uporabljeni tudi leseni tramovi - stropniki, ki pa so morali biti predpisano protipožarno zaščiteni. Zidovi starejših večstanovanjskih zgradb so grajeni v opeki, medtem ko je po drugi svetovni vojni mogoče opaziti naraščanje uporabe betona tudi za gradnjo zidov. $\mathrm{Na}$ uporabo tega je vplivala modnost in uporabnost, predvsem pa dejstvo, da je tovrstnega gradbenega materiala pri nas dovolj. Les kot gradbeni material se je uporabljal le še za izdelavo ostrešij, medtem ko se večjih lesenih večstanovanjskih zgradb pri nas ni gradilo. Prav tako se pri nas v večstanovanjski gradnji ni uveljavila jeklena skeletna gradnja. Večje spremembe v uporabi gradiv so značilne za zadnjih nekaj let.

$\mathrm{V}$ požaru ima različni gradbeni material različne lastnosti (preglednica 1). Uporaba opeke in betona kot glavnih gradbenih materialov je s stališča protipožarnega varstva ugodna, saj ta material preprečuje prehod požara iz enega stanovanja v drugo, hkrati pa dovolj dolgo ohrani celovitost in preprečuje porušitev stavbe. Jeklo je glede požarne varnosti slabši material, saj se njegov elastični modul z naraščanjem temperature hitro zmanjšuje. Kljub temu je mogoče jekleno konstrukcijo ustrezno zaščititi (premazi, obloge ...). Les sicer gori, vendar se pri tem ustvari plast oglja, ki deloma ščiti notranjost. Leseno konstrukcijo je prav tako mogoče zaščititi. TSG dovoljuje brez posebnih omejitev lesene zgradbe do višine pritličje in prvo nadstropje $(P+1)$. Namestitev sistema za avtomatsko gašenje požara pa omogoča gradnjo do višine pritličje in 5 . nadstropja $(P+5)$. Za jekleno konstrukcijo ni podobne višinske omejitve, zahteva pa se odpornost konstrukcije pri požaru.

\subsection{Komunikacije in organiziranost prostorov}

Večina večstanovanjskih stavb ima dvignjeno pritličje tam, kjer je vhod v objekt. Do njega vodijo stopnice. Za vhodnimi vrati je predprostor (vetrolov) s poštnimi nabiralniki. Ta prostor je običajno ločen od glavne komunikacije znotraj objekta, ki sestoji iz hodnikov in stopnišč. Stolpnice imajo poleg navedenega še eno ali dve dvigali. V nasprotju s stolpnicami, ki imajo komunikacijsko jedro običajno v sredini zgradbe, imajo nekateri bloki vertikalne komunikacije prav tako v sredini zgradbe, vendar tako, da imajo eno steno ob zunanji strani objekta, da je čez dan dosežena naravna osvetlitev stopnišča.

Zasnova in izvedba komunikacij v večstanovanjskih zgradbah, $\mathrm{v}$ katerih so stopnišča in hodniki do vhodov v stanovanja odprti od kleti do strehe, je s stališča požarnega varstva posebej slaba. Pri požaru se komunikacija hitro zadimi in onemogoča varen umik vseh, ki so ujeti v zgradbi. Stanje na tem področju poslabšuje dejstvo, da so se do srede 90 . let prejšnjega stoletja vgrajevala lesena vhodna vrata, ki niso dimotesna. Prav pri tem je smernica TSG prinesla novosti, saj glede na karakteristike zgradbe zahteva ustrezno izvedbo (zaščitenih) vertikalnih komunikacij in vhodnih vrat v stanovanja. Gre predvsem za ločitev stopnišča od etažnega hodnika in $s$ tem preprečitev širjenja dima po celotnem objektu.

\subsection{Namembnost prostorov}

Značilnost blokov in stolpnic je, da je bila včasih večina namenjena samo za bivanje ljudi. Zato ima vsako stanovanje (97,9\%) svojo kuhinjo (internet 5), ki je potencialno žarišče požarov. Čeprav so sodobne kuhalne naprave danes izpopolnjene in same največkrat ne povzročijo požara, lahko prav prisotnost ali odsotnost človeškega faktorja pri termični obdelavi hrane povzroči, da se hrana vname in nastane požar.

Del kletnih prostorov večstanovanjskih objektov je bil prvotno namenjen skupnim potrebam (večnamenska soba za hišni 
Preglednica 1: Odpornost ločilnih elementov glede na vrsto materiala in debelino

\begin{tabular}{lll}
\hline Material & Minimalna debelina & Požarna odpornost \\
\hline opeka & $10 \mathrm{~cm}$ & $60 \mathrm{~min}$ \\
\hline beton & $\mathrm{cca} 8 \mathrm{~cm}$ & $60 \mathrm{~min}$ \\
\hline les & & $\begin{array}{l}\text { hitrost gorenja je cca } 0,6 \mathrm{~mm} / \mathrm{min} \text { (odvisno od } \\
\text { vrste lesa in drugih dejavnikov) }\end{array}$ \\
\hline suhomontažna konstrukcija (»gips«) & $3 \mathrm{~cm}$ & $60 \mathrm{~min}$ \\
\hline lesena vrata & & do $20 \mathrm{~min}$ \\
\hline
\end{tabular}

Vir: Egan (1990)

svet, kolesarnica, kurilnica ...), ostali del pa je bil namenjen shrambam stanovalcev. Shrambe stanovalcev so običajno ločene $\mathrm{z}$ lesenimi stenami ali ograjami. Po izkušnjah gasilcev so ob požaru kletni prostori najbolj problematični. V njih namreč ni dnevnega nadzora kot v ostalih stanovanjskih prostorih. Poleg tega se v kleteh shranjuje različne snovi, tudi vnetljive in eksplozivne. Zato je gašenje kletnih prostorov tvegano, saj gasilci nikoli ne vedo, kaj jih čaka v teh prostorih (Kejžar, 2008).

V zadnjih letih je opazno tudi spreminjanje (skupnih) pritličnih prostorov večstanovanjskih objektov v komercialne namene (zlasti za storitvene dejavnosti). Spreminjanje namembnosti nekaterih prostorov večstanovanjskih zgradb načeloma ni problematično, če se ob tem upošteva sodobne principe varstva pred požari.

\subsection{Intervencijske poti}

Pomanjkanje parkirišč ob obstoječih večstanovanjskih zgradbah sili uporabnike, da svoja vozila parkirajo tudi na intervencijskih poteh. To otežuje oziroma celo onemogoča učinkovito intervencijo gasilcev pri požaru. Pri nas je izboljšanje stanja na tem področju odvisno predvsem od ozaveščenosti večine ljudi in represivne politike lokalnih skupnosti.

\subsection{Ogrevanje}

Med stanovanji so večje razlike pri načinu ogrevanja. Večina (79\%) stanovanj ima danes centralno ogrevanje (internet 5). $S$ stališča varstva pred požarom je najvarnejše daljinsko ogrevanje. Požarna statistika kaže, da so dimniški požari po številu takoj za požari v kuhinjah (internet 6; Kušar, 2008). Sodobna tehnologija ogrevanja s trdimi, tekočimi in plinastimi energenti omogoča preprosto upravljanje s kotli, hkrati pa dosega tudi bistveno boljše izkoristke toplote, kar pomeni nižjo temperaturo dimnih plinov in s tem manj možnosti za nastanek dimniških požarov. K zmanjšanju dimniških požarov pripomore redno vzdrževanje kurilnih in dimovodnih naprav.

\subsection{Lastništvo}

Za slovenske večstanovanjske zgradbe je značilno tudi razpršeno lastništvo, ki je predvsem posledica možnosti odkupa družbenih stanovanj konec prejšnjega stoletja. Prav razpršenost lastništva pa otežuje in večkrat onemogoča učinkovito prenovo celotne zgradbe, ki bi zagotovila večjo požarno varnost.

\section{Analiza požarov}

\subsection{Zgodovinski oris razvoja protipožarnih principov $\mathbf{v}$ večstanovanjskih zgradbah}

Iz zgodovinskega pregleda razvoja mest je razvidno, da so predvsem požari zavirali rast in napredek mest. Hkrati so bili prav požari tisti, ki so pripomogli $\mathrm{k}$ velikim spremembam v uporabi gradbenih materialov in tako dejansko spreminjali arhitekturno podobo mest (Kušar, 2006). V nasprotju s potresnimi gradbenimi principi se je pri nas dolgo ohranil sistem protipožarne zaščite, katerega osnova so bili statuti mest in kasneje požarni redi. Prvi redi so se pojavili že v 13. stoletju, pri nas pa je pomemben mejnik Požarni red za deželo Kranjsko, ki je izšel leta 1773 in je bil napisan tudi v slovenščini. S požarnimi redi je oblast poskušala zmanjšati nastanek požarov in škodo, saj so dokaj podrobno razčlenjevali posamezne zahteve varstva pred požarom ter ukrepe, ki so potrebni za preprečevanje nastanka in širjenja požara, hitro evakuacije in zmanjšanje škode. Uresničevanje teh zahtev je pripomoglo $k$ zmanjšanju števila požarov, in to predvsem na račun zamenjave lesa kot gorljivega gradbenega materiala z negorljivim - opeko, opečnimi strešniki in kasneje betonom (Kušar, 2008). S tem so dosegli tudi preprečevanje širjenja požara med stanovanji. Prenos požara skozi vhodna vrata so običajno preprečili gasilci, ki so nato tudi prezračili komunikacije.

Zgodovinska izkušnja nam omogoča lažje razumeti, zakaj je pri nas lesena gradnja večstanovanjskih objektov skoraj zamrla. 
Hkrati lahko spremljamo tudi pospešen razvoj gasilstva na Slovenskem, ki je poleg strogo strokovne imelo tudi velik družabni in narodnostni pomen. Kombinacija negorljivih materialov in gasilstva je bila dokaj uspešen način preprečevanja velikih požarov. Posledica tega pa je bila, da razvoj zakonskih predpisov ni sledil razvoju ostalega gradbenega področja. Tako v Jugoslaviji še leta 1988 ni bilo sistemsko urejenih protipožarnih predpisov. Pri projektiranju se je delno sledilo različnim tujim predpisom, zlasti nemškim, kar je velikokrat povzročalo zmedo. Naši tedanji predpisi pa tehnično niso bili učinkoviti, bili so celo škodljivi in niso zagotavljali požarno varne gradnje (Urbas, 1988). Osamosvojitev, pridružitev EU in sprejemanje novih gradbenih predpisov so tudi na tem področju napravili velik korak. S prevzemanjem dobrih lastnih in tujih (TSG se sklicuje na švicarske, ameriške in nemške predpise) izkušenj, zlasti Nemčije, Švice, ZDA, in sprejemanjem teh v našo zakonodajo je nastal nov okvir za varno gradnjo. Zaradi hitrega razvoja znanosti in stroke se ta okvir hitro spreminja in dopolnjuje.

\subsection{Analiza požarov $v$ večstanovanjskih zgradbah}

Zmanjševanje števila požarov je danes omejeno na gradbene ukrepe za preprečevanje širjenja požara in izvedbo evakuacije, veliko manj pozornosti pa se posveča analizi vzrokov požarov in načinom preprečevanja njihovega nastanka. $V$ ta namen je bilo izvedeno vrednotenje statističnih podatkov o požarih $\mathrm{v}$ večstanovanjskih zgradbah v Sloveniji. V obravnavanem obdobju - v letu 2005 in času od 1. 10. 2006 do 31. 12. 2008 - je bilo v večstanovanjskih zgradbah 859 požarov, kar pomeni en požar na 21 večstanovanjskih zgradb oziroma 4,8 požara na 100 večstanovanjskih zgradb. Pet požarov in več je bilo v 35 občinah, v katerih je 13.874 večstanovanjskih zgradb oziroma $77,1 \%$ vseh takih zgradb v Sloveniji. Požari v teh občinah pomenijo $85,6 \%$ vseh požarov v večstanovanjskih zgradbah pri nas. Najbolj so bile ogrožene zgradbe v Škofji Loki, kjer je na 100 zgradb prišlo 14,9 požara, v Tolminu (12,0), Novi Gorici $(11,7)$, Lendavi $(11,1)$ in Kanalu (10,2), najnižje vrednosti pa imajo od obravnavanih občin Ravne na Koroškem (2,9), Krško $(2,8)$, Novo mesto $(2,5)$ in Radovljica $(2,3)$.

Kar zadeva vzroke požara, je v obravnavanem času največkrat zagorelo v kuhinji $(39,1 \%)$. Pri tem prednjačijo občine Ajdovščina, Novo mesto, Trbovlje, Žalec in Hrastnik, v katerih je več kot polovica požarov nastala v kuhinjah. Število kuhinjskih požarov bi bilo mogoče zmanjšati ali celo odpraviti, če bi bila oseba, ki je navadno v bližini, pravočasno opozorjena na nastanek požara. Tako bi lahko pravočasno ukrepala in preprečila ali nastanek požara ali njegovo razširitev.
Na drugem mestu je požar v kurilnih in dimovodnih napravah $(17,2 \%)$. Glede na opise je požar običajno nastal v starejših zgradbah, ki imajo individualna kurišča na trdo gorivo (les) ter je varnost njihovih kurilnih naprav in dimnikov problematična. $\mathrm{V}$ takih primerih gre velikokrat za bivališča socialno ogroženih oseb, ki si drugačnega načina ogrevanja ne morejo privoščiti. Največji delež tovrstnih požarov je bil v občinah Ilirska Bistrica, Tolmin, Kanal, Idrija in Črnomelj (več kot $50 \%$ ). Najmanjši delež tovrstnih požarov pa je v največjih slovenskih mestih (Ljubljana 0,81 \%, Kranj 6,45 \%, Velenje $7,1 \%$ in Maribor 10,5\%), kar je posledica varnejšega načina ogrevanja (daljinsko ogrevanje, plin ...).

\section{Stanje slovenskih večstanovanjskih zgradb s stališča požarne ogroženosti}

\subsection{Preprečevanje nastanka požara}

Kot je bilo omenjeno, je s stališča osnovnega gradbenega materiala konstrukcije obravnavanih večstanovanjskih zgradb stanje pri nas dobro, saj je $84 \%$ večstanovanjskih zgradb zgrajenih iz negorljivega betona, opeke ali kamna, lesenih zgradb pa je manj kot $1 \%$. Večstanovanjskih zgradb z jekleno nosilno konstrukcijo pri nas ni veliko, tako da jih tudi popis iz leta 2002 ne uvršča v svoj razred, ampak v kategorijo »drugo«, ki obsega tudi kombinacije različnih materialov (les-opeka, opeka-beton ...).

Kakovosti vgrajenih napeljav ni mogoče preveriti, zato za to področje ni mogoče podati ocene. Analiza požarov pa je pokazala, da so lahko tudi napake pri napeljavah in strojih ter napravah v stanovanjih vzrok za požar.

\subsection{Odkrivanje in javljanje požara}

Terensko delo je pokazalo, da se tehničnih sredstev za odkrivanje in javljanje požarov pri nas skoraj ne uporablja. Razlogov za to je verjetno več. Najprej gre predvsem za to, da tovrstna sredstva za stanovanja niso zakonsko predpisana oziroma jih tudi zavarovalnice ne spodbujajo dovolj. Drug razlog je verjetno nevednost in nezaupanje $\mathrm{v}$ sredstva ter neosveščenost stanovalcev.

Javljanje požarov je običajno telefonsko, kar omogočajo stacionarna in mobilna telefonska omrežja, $s$ katerimi je prepredena Slovenija. Večjo varnost je mogoče doseči z namestitvijo naprav za odkrivanje in javljanje požarov ter njihovo povezavo $\mathrm{z}$ ustrezno varnostno ali gasilsko službo. 
Preglednica 2: Dejavniki in odvisnost »ogroženosti« stavbe od višine

\begin{tabular}{|c|c|c|c|c|}
\hline Skupina & Etaže & $\begin{array}{l}\text { Ocenjena višina } \\
\text { zgradbe }\end{array}$ & $\begin{array}{l}\text { Možnost gasilske } \\
\text { intervencije }\end{array}$ & $\begin{array}{l}\text { današnje zahteve za } \\
\text { evakuacijsko pot }\end{array}$ \\
\hline $\begin{array}{l}\text { požarno manj ogrožene } \\
\text { zgradbe }\end{array}$ & od $P$ do $P+2$ & $8 \mathrm{~m}$ & prenosna lestev & splošne zahteve \\
\hline $\begin{array}{l}\text { požarno srednje ogrožene } \\
\text { zgradbe }\end{array}$ & od $P+2$ do $P+7$ & do $22 \mathrm{~m}$ & $\begin{array}{l}\text { avtomobilska vrtljiva } \\
\text { lestev }\end{array}$ & $\begin{array}{l}\text { splošne zahteve + zahteve za } \\
\text { zaščiteno stopnišče }\end{array}$ \\
\hline $\begin{array}{l}\text { požarno bolj ogrožene } \\
\text { zgradbe }\end{array}$ & $P+8$ in več & $\operatorname{nad} 22 \mathrm{~m}$ & $\begin{array}{l}\text { avtodvigalo s košaro } \\
\text { (do } 50 \mathrm{~m} \text { ) }\end{array}$ & $\begin{array}{l}\text { splošne zahteve + posebne } \\
\text { zahteve za zaščitena stopnišča } \\
\text { v visokih zgradbah }\end{array}$ \\
\hline
\end{tabular}

\subsection{Evakuacija}

Ocenitev sedanjega stanja je pokazala pomanjkljivosti na področju evakuacije. Zasnova zgradbe z osrednjim odprtim komunikacijskim jedrom in lesenimi vhodnimi vrati $\mathrm{v}$ stanovanja je $s$ stališča požarnega varstva izrazito slaba in ne ustreza sodobnim zahtevam.

Varnost ljudi $\mathrm{v}$ teh stavbah se zmanjšuje $\mathrm{z}$ višino zgradbe (preglednica 2), saj zahteva evakuacija z zunanje strani večje napore in tudi boljšo tehnično opremljenost gasilcev. Glede na kriterije iz preglednice 2 bi lahko večstanovanjske zgradbe glede požarne varnosti razdelili v tri kategorije: požarno manj ogrožene zgradbe, požarno srednje ogrožene zgradbe in požarno bolj ogrožene zgradbe.

Statistični podatki kažejo, da je glede na kriterije iz preglednice $2 \mathrm{v}$ najbolj ogroženem razredu visokih stavb, grajenih pred letom 1995, 6,5\% vseh slovenskih večstanovanjskih zgradb, ki so v 28 občinah. Največ jih je v Ljubljani (423), največji delež pa imajo v Velenju (17 \%), Škofji Loki (16\%), Celju in Murski Soboti (po 13 \%) ter v občinah ob Savi od Ljubljane do Brežic ter posameznih večjih industrijskih središčih (slika 3). Ob tem je treba poudariti, da uvrstitev med najbolj ogrožene še ne pomeni večje verjetnosti za nastanek požara, temveč le težave pri gašenju in evakuaciji ob morebitnem izbruhu požara.

Srednje ogroženih večstanovanjskih zgradb (višine od pritličje +3 do pritličje +7 etaž) je v Sloveniji $47,5 \%$ in predstavljajo največjo skupino med tovrstnimi zgradbami. Največ takih zgradb je v Ljubljani (2.313), največji delež pa zavzemajo v občinah Žužemberk (100 \%), Cerkno (73,9 \%) in Piran $(72,5 \%)$ (slika 4).

\subsection{Možnost intervencije}

Slovenska gasilska služba učinkovito opravlja svoje poslanstvo kljub težavam, s katerimi se srečujejo zlasti prostovoljna gasil- ska društva (oprema, vrednotenje njihovega dela ...). Zato do intervencij lahko pride v zelo kratkem času, kar je pri požaru pomembno. Problematičen pa je lahko dostop do objekta zaradi zaparkiranosti. Razmere so specifične za vsak posamezni objekt in so odvisne tudi od dneva, ure in zavesti prebivalcev. Zato stanja na tem področju ni mogoče podrobno oceniti.

\section{Diskusija}

Načini zmanjševanja požarov v stanovanjskih zgradbah se med državami razlikujejo. Najbolj razviti so glede tega v ZDA (Bukowski in Budnick, 1995; Butry idr., 2008) in skandinavskih državah (Ahačič, 2006). Eden od vzrokov za to je tudi dejstvo, da je v teh državah les pomemben gradbeni material. Izboljšanje stanja na tem področju poteka tako prek splošnih zahtev za odpornosti konstrukcij in prenosa požara, zlasti pa so usmerjeni v zgodnje odkrivanje nastanka požara (Brown, 2005) in hitro gašenje. Požar je namreč najlažje pogasiti, ko še ni razvit.

Današnja tehnologija ponuja več oblik zaznavanja požara in načina prenosa podatkov o požarih. Najbolj preprosti in ceneni so javljalniki dima, ki z zvočnim signalom opozorijo na požar. Oseba v bližini se lahko zato hitro odzove in požar pogasi. Rezultati so pokazali, da največkrat zagori v kuhinjah in prav število teh požarov bi bilo mogoče najlažje zmanjšati. $V$ Sloveniji se tovrstne naprave žal počasi uveljavljajo. Zanimivi so izsledki raziskav iz zahodnih držav, v katerih uporabo teh naprav predpisujejo in spodbujajo. Pri tem se je kot učinkovita izkazala zlasti zavarovalniška politika z nižjimi premijami za zgradbe, ki imajo nameščene te naprave. Rezultati danske študije (Ahačič, 2006) in izkušnje držav, v katerih so javljalniki dima predpisani (ZDA, Velika Britanija, Švedska), potrjujejo, da so ti zmanjšali število smrtnih žrtev za 40 \% (internet 3).

V ZDA, kjer sta najpogostejša vzroka za požar v stanovanjih povezana s kuhanjem ( $32 \%$ vseh požarov v stanovanjih v ZDA) in $\mathrm{z}$ ogrevanjem ( $16 \%$ vseh požarov v stanovanjih v ZDA) (internet 7), so ugotovili, da samo javljalniki ne zadostujejo za 


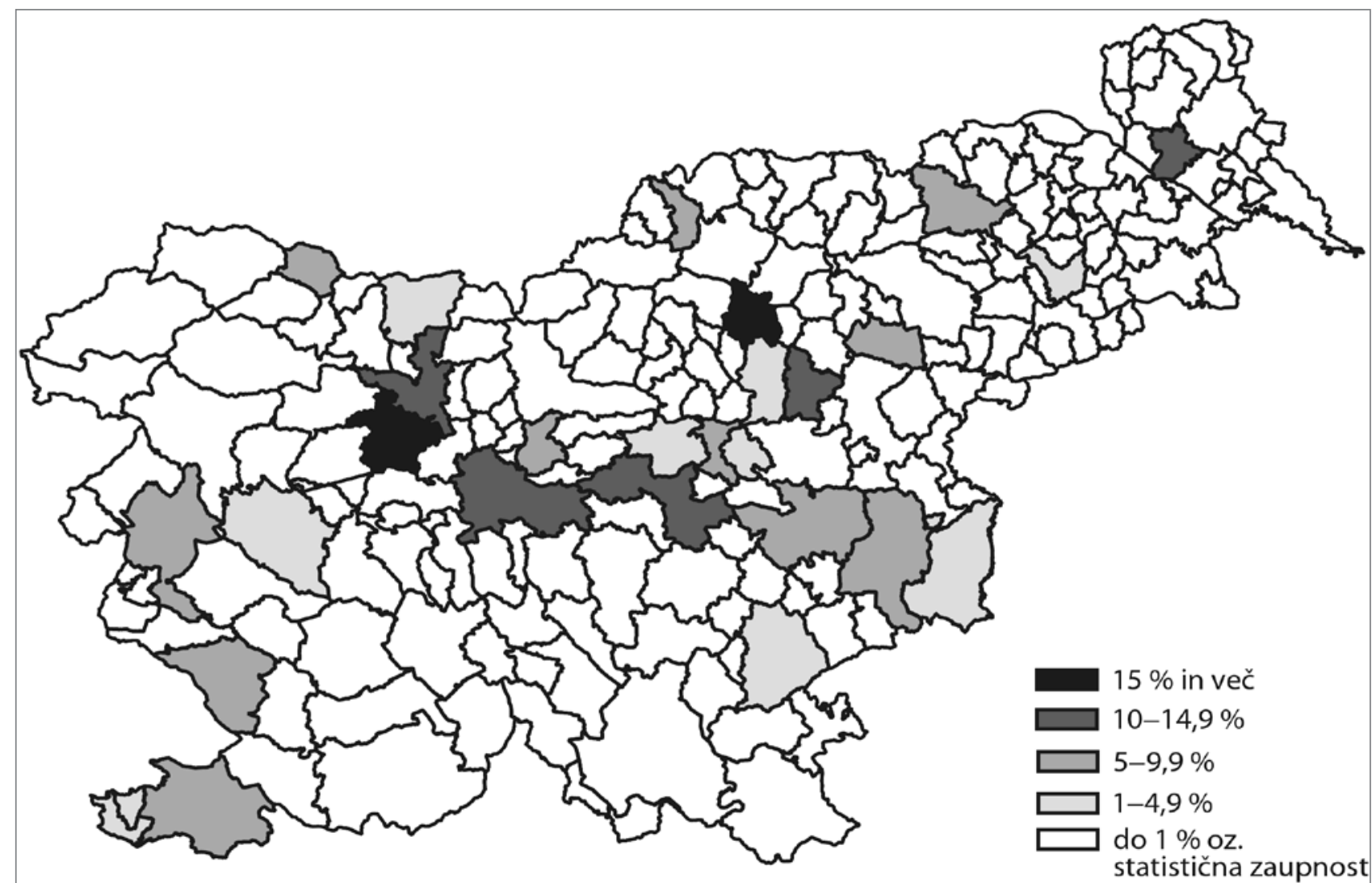

Slika 3: Delež požarno bolj ogroženih večstanovanjskih zgradb po občinah (vir: Statistični urad Republike Slovenije, 2009)

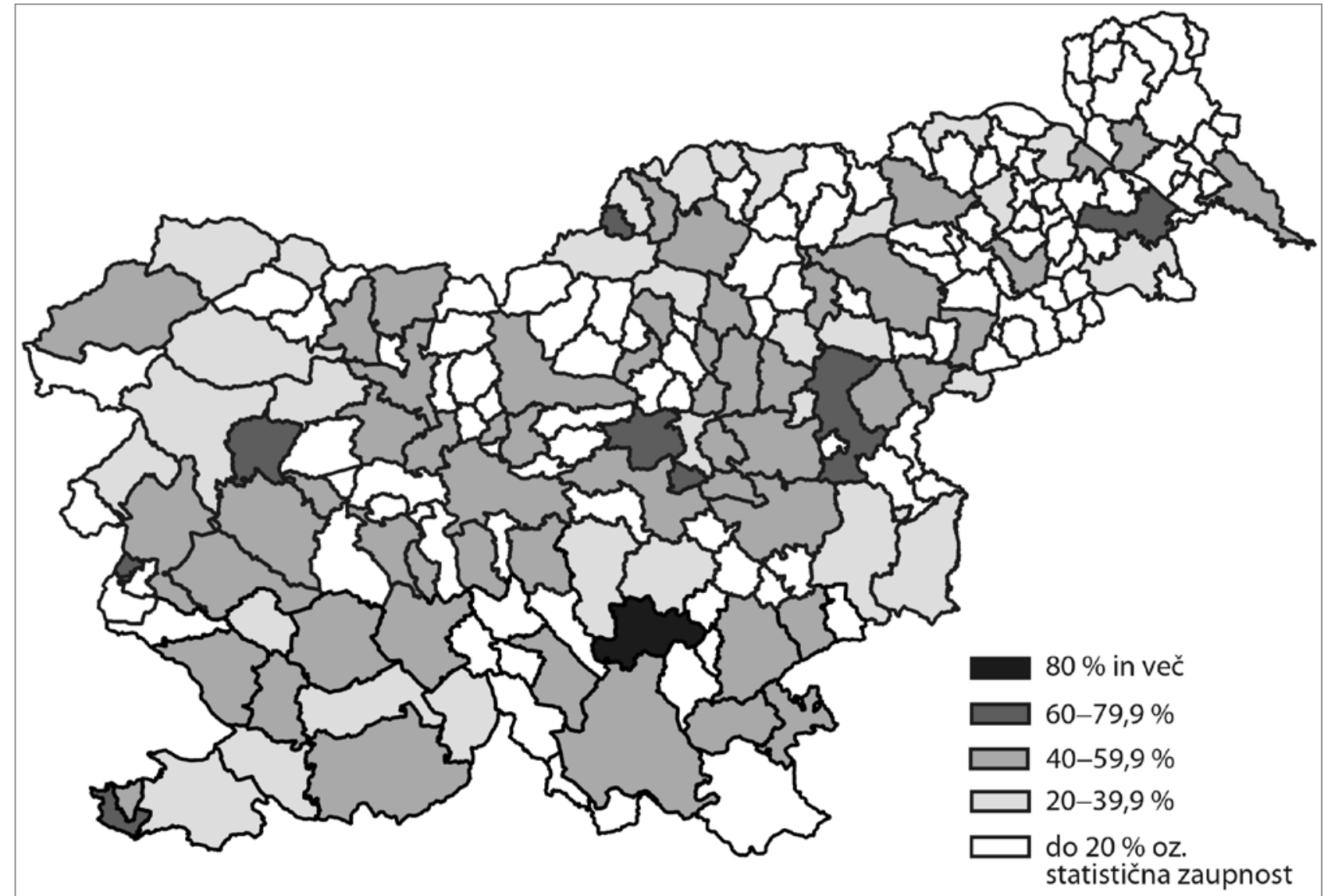

Slika 4: Delež požarno srednje ogroženih večstanovanjskih zgradb po občinah (vir: Statistični urad Republike Slovenije, 2009) 
protipožarno varnost, in sedaj pospešeno raziskujejo možnosti vgradnje avtomatskih gasilnih naprav tudi v enostanovanjske hiše, opravljajo pa tudi tako imenovane analize »cost-benefit « o ekonomski smiselnosti namestitve naprav za samodejno gašenje v stanovanju (Brown, 2005; Butry idr. 2008; internet 2). $\mathrm{V}$ naseljih, v katerih je skupaj več stolpnic, bi bilo glede na razmerje cene osnovnega postrojenja (vir vode, črpalka ...) ter cene razvoda in pršilnih šob smiselno izdelati eno postrojenje za celoten niz stolpnic. Od tega bi nato razvod sistema potekal v vsako stolpnico, kjer bi bili pršilniki nameščeni v kletnih prostorih, komunikacijah in tudi v vsakem stanovanju. $\mathrm{Ob}$ tem je treba ponovno poudariti, da je namestitev sistema za samodejno gašenje v ZDA obvezna za vse večstanovanjske zgradbe, ki imajo 4 ali več etaž, in to že od leta 1992 (Bukowski in Budnick, 1995). Podobno bodo ustrezno raven varstva pred požarom v 7- in 8-nadstropnih večstanovanjskih lesenih zgradbah, ki jih gradijo v Berlinu in kraju Vaexjoe na Švedskem, dosegli s pomočjo negorljivih obložnih materialov in sistema za avtomatsko gašenje (Linse in Natterer, 2008; internet 8).

Bolj preprosta in cenejša sredstva so gasilne kapsule ali ampule, ki vsebujejo ovoj, občutljiv na temperaturo in gasilno sredstvo. Pri povečani temperaturi ovoj razpade in pri tem se razprši gasilno sredstvo, ki pogasi požar. Kapsule se običajno namesti nad mesto, kjer obstaja možnost izbruha požara. $V$ stanovanjih se namestitev takih kapsul priporoča nad štedilnikom. Novosti in rešitve, prikazane na ljubljanskem pohištvenem sejmu leta 2008, kažejo, da proizvajalci še ne razmišljajo o tovarniški vgradnji požarnovarnostnih naprav v kuhinjske elemente.

Potreben ukrep v obravnavanih zgradbah bi bil zamenjava sedanjih vrat s požarno odpornimi, dimotesnimi vrati. Ukrep ne zahteva hkratne zamenjave vseh vrat, čeprav bi bilo to najbolje in tudi finančno najugodneje, zaradi razdrobljenosti lastništva pa je verjetno edini mogoč. Namen tega ukrepa je preprečiti prenos požara, zlasti dima, $\mathrm{v}$ stanovanje in $\mathrm{s}$ tem omogočiti daljši čas za evakuacijo.

Koristen, vendar verjetno (ekonomsko) neupravičen in težko izvedljiv ukrep bi bila namestitev naprav za odvod dima in toplote ter ureditev varnega stopnišča, skladnega z zahtevami TSG. Ukrep bi namreč največkrat zahteval prevelike posege $\mathrm{v}$ strukturo in oblikovanje zgradbe (izvedba dodatnih vertikalnih jaškov in hodnika v vsaki etaži ter izgradnja novih varnih stopnic).

Na podlagi uvedenih in neuvedenih ukrepov lahko zavarovalnica določi stopnjo tveganja in $s$ tem tudi višino zavarovalne premije. Zavarovalnice lahko pomembno vplivajo na razvoj varnostnih principov in tako izobražujejo ljudi o pomembnosti npr. protipožarnih ukrepov in $s$ tem tudi varnosti. Njihova vloga je v nekaterih državah zelo pomembna, saj so $s$ politiko premij generator razvoja in uveljavitve varnostnih principov. $\mathrm{V}$ Švici tako združenje kantonalnih požarnih zavarovanj (Association des établissements cantonaux d'assurance incendie) določa požarnovarnostne principe, ki jih je treba upoštevati. Iz informacij, ki smo jih dobili pri Zavarovalnici Triglav, ki ima v Sloveniji največji delež stanovanjskih zavarovanj, izhaja, da je za večje znižanje zavarovalniških premij potrebno več kot le namestitev javljalnikov v stanovanja. Da je javljalnik ustrezen, se prizna le, če ima ta certifikat ustreznosti, ki ga izda pristojna institucija, pooblaščena s strani urada za standardizacijo in meroslovje. Javljalnik pomeni 5 -odstotni popust pri osnovnem zavarovanju in 10-odstotni popust pri zavarovanju stanovanjskih premičnin. Večji (do 15-odstotni) popust je mogoče pridobiti le, če je sistem povezan z dežurno gasilsko enoto, 12-odstotni, če je sistem povezan z dežurnim centrom, in 10-odstotni, če je poleg javljalnika organizirana 24-urna čuvajska služba.

\section{Sklep}

V Sloveniji je skoraj tretjina stanovanj $\mathrm{v}$ večstanovanjskih zgradbah. Povprečna stavba ima 13 stanovanj, kar pomeni, da so to pretežno srednje veliki objekti. $S$ požarno varnostnega stališča je dobro, da je velik delež zgradb zgrajenih iz negorljivih materialov. Najbolj problematične so tako visoke zgradbe, predvsem zaradi svoje evakuacije. Visokih zgradb je v Sloveniji 1.171 ali $6,5 \%$ vseh večstanovanjskih zgradb. Njihov delež po občinah je prikazan v članku.

Sedanja varnostna zakonodaja dovolj dobro ureja gradbenoarhitekturne ukrepe za zmanjševanje števila požarov, pogreša pa se ukrepe, ki bi tudi prebivalstvo silili k ustreznemu ravnanju. Take ukrepe se najlažje izvede $s$ pomočjo finančnih stimulacij (zavarovalnice) in medijsko odmevnih akcij.

Posebej problematični so kletni prostori zaradi nevarnih (vnetljivih in nevarnih) snovi, ki jih tam shranjujejo prebivalci. Tu se pogreša jasen ukrep na ravni države, ki bi lastnike in uporabnike stanovanj podučil ter nato spodbudil $k$ ustreznemu shranjevanje stvari in snovi. Čeprav določeni predpisi, ki urejajo tudi to področje že obstajajo (uporablja se jih predvsem v industriji in trgovini), bi bila verjetno smiselna njihova transformacija in prilagoditev v obliko kratkih navodil za uporabo nebivalnih kletnih prostorov v stanovanjskih zgradbah.

$\mathrm{Z}$ raziskavo pa se je pokazal še en problem. Današnje modno oblikovanje in svobodno razvrščanje pročelni odprtin večstanovanjskih objektov posveča premalo pozornosti prenosu ognja po pročelju, kar se kasneje včasih sicer rešuje po izgradnji, včasih pa tudi ne. Večja uporaba lesa v gradnji - tudi 
$\mathrm{v}$ večstanovanjskih objektih - bo zahtevala še več znanja na tem področju in skrbnega projektiranja, izvedbe in nadzora protipožarne varnosti na tem področju.

Dr. Domen Kušar, univ. dipl. inž. arh., docent Univerza v Ljubljani, Fakulteta za arhitekturo, Ljubljana, Slovenija E-pošta: domen.kusar@fa.uni-lj.si

Dr. Vojko Kilar, univ. dipl. inž. grad., izredni profesor Univerza v Ljubljani, Fakulteta za arhitekturo, Ljubljana, Slovenija E-pošta:vojko.kilar@fa.uni-lj.si

\section{Viri in literatura}

Ahačič, M. (2006): Požarni javljalniki rešujejo življenja. Požar 12(3), str. 13-19.

Bajde, M. (2002): Požarna zaščita lesa in lesenih konstrukcij. V: Varstvo pri delu, varstvo pred požari in medicina dela, str. 234-243. Ljubljana, Univerza v Ljubljani, Fakulteta za kemijsko tehnologijo, Oddelek za tehniško varnost.

Brown, H. (2005): Economic Analysis of residental fire sprinkler systems. Dostopno na: http://fire.nist.gov/bfrlpubs/fire05/PDF/f05085. pdf (sneto 3. 11. 2009).

Bukowski, R. W., in Budnick, E. K. (1995): Guide for the implementation of PL 102-522 for fire alarm and automatic sprinkler installations (1995). Dostopno na: http://fire.nist.gov/bfrlpubs/fire95/PDF/ f95067.pdf (sneto 12.10.2008).

Butry, D. T., Brown M. H., in Fuller, S. K.(2008): Benefit-Cost analysis of residential fire - sprinkler systems. Dostopno na: http://fire.nist. gov/bfrlpubs/build07/PDF/b07025.pdf (sneto 12. 10. 2008)

Dujić, B. (2009): Poenostavljanje metode projektiranja požarnovarnih lesenih konstrukcij. V: Lopatič, J., Markelj, V., in Saje, F. (ur.): Zbornik 31. zborovanja gradbenih konstruktorjev, str. 145-152. Ljubljana, Slovensko društvo gradbenih konstruktorjev.

Egan, D. (1990): Građevinske konstrukcije i požar. Beograd, Građevinska knjiga.

Galonja, S. (2008): Visoke stavbe - poudarki mestnega prostora. Požar 14(3), str. 38-40.

Goode, M. G. (2004): Fire protection of structural steel in high-rise buildings. Dostopno na: http://fire.nist.gov/bfrlpubs/build04/PDF/ b04047.pdf (sneto 3. 11. 2009).

Hajdukovič, M. (1995): Gradbeni ukrepi za preprečitev širjenja požara in dima po objektu. Požar, 1(1), str. 12-16.

Internet 1: http://www.sos112.si/slo/tdocs/bilten/ (sneto 24. 8. 2009).

Internet 2: http://www.firesafety.gov/citizens/sprinklers/index.shtm (sneto 2. 6. 2008).

Internet 3: http://www.mieterverein-uenchen.de/verbraucherthemen/brandschutz.htm (sneto 13. 11. 2007).

Internet 4: http://www.stat.si/Popis2002/si/definicije_in_pojasnila_6. html (sneto 20. 11. 2008).

Internet 5: http://www.stat.si/Popis2002/si/rezultati_slovenija_stavbe. htm (sneto 20. 11. 2008).
Internet 6: http://spin.sos112.si/Pregled/GraficniPrikaz/default_neprijav.aspx?Aspx Auto DetectCookieSupport=1 (sneto 5. 1. 2009).

Internet 7: http://www.nfpa.org/ (sneto 18. 6. 2007).

Internet 8: http://www.vallebroar.se/ (sneto 11. 9. 2009)

Kejžar, M. (2008): Visoki stanovanjski objekti, gasilci, gašenje in reševanje. Požar, 14(3), str. 43-47.

Kilar, V. (2004). Ocena potresne ogroženosti stanovanjskih stavb v Sloveniji. AR, Arhitektura raziskave, 4(1), str. 62-65.

Kilar, V., in Kušar, D. (2009): Ocena potresne ogroženosti večstanovanjskih zgradb v Sloveniji. Dostopno na: http://giam.zrc-sazu.si/ sites/default/files/ags49103.pdf (sneto 2. 11. 2009).

Kramer, J. (2008): Požarna varnost v visokih stavbah. Požar, 14(3), str. $41-42$.

Kuligowski, E. D. (2008): Modeling human behavior during building fires. Dostopno na: http://fire.nist.gov/bfrlpubs/fire09/PDF/f09018. pdf (sneto 3. 11. 2009).

Kušar, D. (2006): Varnost v zgradbah. Doktorska disertacija. Ljubljana, Univerza v Ljubljani, Fakulteta za arhitekturo.

Kušar, D. (2008): Protipožarna varnost večstanovanjskih zgradb pri nas. AR, Arhitektura raziskave, 8(1), str. 14-19.

Linse, T., in Natterer, J. (2008): A seven floor residental building almost completely made of timber - Report of a pilot project. Bauingenieur, 83 str. 531-539.

Lo, S. M. (1999): A fire safety assessment system for existing buildings. Dostopno na: http://www.springerlink.com/ content/03m520j8cwwyevkh (sneto 3. 11. 2009).

Lo, S. M., Hu, B. Q., Liu, M., in Yuen, K. K. (2005): On the use of reliability interval method and grey relational model for fire safety ranking of existing buildings. Dostopno na: http://www.springerlink.com/ content/7025I343566666kr/fulltext.pdf (sneto 4. 11. 2009).

Long, S., Qiyuan, X., Xudong, C., Long, C., Yong, Z., in Ruifang, Z. (2009): Developing a database for emergency evacuation model. Dostopno na: http://www.sciencedirect.com (sneto 2. 11. 2009).

Ministrstvo za okolje in prostor RS (2007): Tehnična smernica TSG-1001: 2007 - Požarna varnost v stavbah. Ljubljana.

National institute of standards and technology (2005): Collapse of the World trade center towers. Final report. Federal building and fire safety investigation of the World trade center disaster. Dostopno na: http://fire.nist.gov/bfrlpubs/fire05/PDF/f05119.pdf (sneto 4. 11. 2009).

Nussmuller W. (2009): Strokovna ekskurzija (osebni vir 25. 9. 2009). Oblak J. (2007): Požarni red. Tipkopis.

Orožen Adamič, M. (1995): Potresna ogroženost Ljubljane. Dostopno na: http://giam.zrc-sazu.si/zbornik/Orozen35.pdf (sneto 4. 11. 2009).

Orožen Adamič, M., in Perko, D. (1996): Potresna ogroženost občin in naselij v Sloveniji. Dostopno na: http://giam.zrc-sazu.si/zbornik/ Orozen_36.pdf (sneto 4. 11. 2009).

Pajek, L., (2008): Požarna zaščita betonskih konstrukcij. Požar, 14(1), str. 50-52.

Pravilnik o minimalnih tehničnih zahtevah za graditev stanovanjskih stavb in stanovanj. Uradni list RS št. 125/2003. Ljubljana. 
Rebec, A. (2006): Fire resistance of structures. V: Conference heritage protection international, str. 26-27. Ljubljana, Slovensko združenje za požarno varnost.

Slak, T., in Kilar, V. (2005): Potresno odporna gradnja in zasnova konstrukcij v arhitekturi. Ljubljana. Univerza v Ljubljani, Fakulteta za arhitekturo.

Statistični urad Republike Slovenije (2003): Popis prebivalstva, gospodinjstev in stanovanj Slovenije 2002. Ljubljana.

Statistični urad Republike Slovenije (2009): Popis prebivalstva, gospodinjstev in stanovanj Slovenije 2002. Izpisi izbranih križanj podatkov, dobljenih s popisom. Ljubljana.

Šijanec-Zavrl, M. (1997): Energetska obnova stanovanjskih stavb v Sloveniji. Gradbeni vestnik, 46 (11/12), str. 318-327.

Tomšič, M. (2005): Toplotna zaščita in sanacije streh. V: Seminar Dobra gradbena praksa pri energetski sanaciji stavb. Ljubljana, Gradbeni inštitut ZRMK.

Urbas, J. (1988): Varstvo pred požari v luči gradbenih predpisov. Ujma, 2, str. 97-99.

Vidrih, R. (2008): Potresna dejavnost zgornjega Posočja. Ljubljana, Agencija RS za okolje, Urad za seizmologijo in geologijo.

Watts, J. M., in Kaplan, M. E. (2001): Fire risk index for historic buildings. Dostopno na: http://www.springerlink.com/content/ w77m19614j886055/fulltext.pdf (sneto 3. 11. 2009).

Wong, L. T., in Lau, S. W. (2007): A fire safety evaluation system for prioritizing fire improvements in old high-rise buildings in Hong Kong. Dostopno na: http://www.springerlink.com/ content/5478g0u14167r581/fulltext.pdf (sneto 3. 11. 2009).

Zakon o varstvu pred požarom. Uradni list RS št. 3/2007. Ljubljana.

Zhao, C. M., Lo, S. M., Lu, J. A., in Fang, Z. (2004): A simulation approach for ranking of fire safety attributes of existing buildings. Dostopno na: http://www.sciencedirect.com (sneto 27. 10. 2009).

Zupančič Strojan, T., Kilar, V., Novljan, T., Lah, L., Hočevar, M., Cirman, A., idr. (2003): Konkurenčnost Slovenije 2001-2006. Raziskovalno poročilo. Ljubljana, Univerza v Ljubljani, Fakulteta za arhitekturo.

Žarnić, R. (2005): Lastnosti gradiv. Ljubljana, Univerza v Ljubljani, Fakulteta za gradbeništvo in geodezijo. 